\title{
Neutrophilic-lymphocytes and platelet-lymphocytes ratios as predictors for acute perforated appendicitis in children
}

\author{
Raquel N. De La Cruz-Vallejo ${ }^{1}$, Ely Quispe-Zaga², and Wendy Nieto-Gutiérrez ${ }^{3 *}$ \\ ${ }^{1}$ Escuela de Medicina Humana, Universidad Nacional de San Cristóbal de Huamanga, Ayacucho; ${ }^{2}$ Servicio de Cirugía Pediátrica, Hospital Regional \\ de Ayacucho, Ayacucho; ${ }^{3}$ Unidad de Investigación para la Generación de Síntesis de Evidencia en Salud, Vicerrectorado de Investigación, \\ Universidad San Ignacio de Loyola, Lima. Perú
}

\begin{abstract}
Background: This study aimed to evaluate the neutrophil-lymphocyte (NLR) and platelet-lymphocyte (PLR) ratios as markers of perforated appendicitis. Methods: We conducted a cross-sectional analytical study. We performed a secondary analysis of a population of pediatric patients who underwent appendectomy between 2017 and 2019 at the Regional Hospital of Ayacucho, Peru. Logistic regression models were used to analyze markers (NLR and PLR) and perforated appendicitis. Later, ROC (receiver operating characteristic) curves were constructed, and sensitivity, specificity, and likelihood ratios were estimated. Results: We identified $31 \%$ of perforated appendicitis in 203 patients. A significant association was observed between perforated appendicitis and NLR values > 10.4 (odds ratio [OR]: $2.53 ; 95 \%$ confidence interval [95\% Cl]: 1.27-5.05) and PLR > 284 (OR: 2.11; 95\% Cl: 1.09-4.08) in the adjusted analysis. For these models, the areas under the curve were 0.74 (95\% Cl: 0.67 - 0.81) for both variables. With a cut-off point of $30 \%$ probability of perforated appendicitis, we observed sensitivity of $77.78 \%$ for both NLR and PLR (likelihood ratio +2.37 and +2.14 , respectively), and specificity of $67.14 \%$ and $63.57 \%$ for NLR and PLR (likelihood ratio -0.33), respectively. Conclusions: Our study showed a significant association between NLR and PLR and acute perforated appendicitis. Future studies should validate the model and corroborate the performance of these markers.
\end{abstract}

Keywords: Appendicitis. Pediatrics. Neutrophils. Blood platelets. Lymphocyte count.

\section{Relación neutrófilos-linfocitos y relación plaquetas-linfocitos como predictores para apendicitis aguda perforada en niños}

\section{Resumen}

Introducción: El objetivo del estudio fue evaluar la relación neutrófilos-linfocitos (RNL) y la relación plaquetas-linfocitos (RPL) como marcadores de apendicitis perforada. Métodos: Se llevó a cabo un estudio analítico transversal. Se realizó el análisis secundario de una población de pacientes pediátricos sometidos a apendicectomía, entre 2017 y 2019, en el Hospital Regional de Ayacucho, Perú. Para el análisis de los marcadores (RNL y RPL) y la apendicitis perforada se utilizaron modelos de regresión logística, de los cuales se construyeron curvas ROC (Receiver Operating Characteristic) y se estimaron la sensibilidad, la especificidad y la razón de verosimilitud. Resultados: Se identificó apendicitis perforada en el $31 \%$ de un total de 203 pacientes. Se observó una asociación significativa entre la apendicitis perforada y los valores > 10.4 de RNL (razón de momios [RM]: 2.53; intervalo de confianza del 95\% [IC 95\%]: 1.27-5.05) y > 284 de PLR (RM: 2.11; IC 95\% 1.09 - 4.08) en el análisis ajustado. Para estos modelos, las áreas bajo la curva fueron de 0.74 (IC 95\%: 0.67 - 0.81) para

\section{Correspondence:}

*Wendy Nieto-Gutiérrez

E-mail: wendy_nieto22@ @otmail.com
Available online: 16-12-2021

Date of reception: 28-03-2021

Date of acceptance: 29-07-2021

DOI: 10.24875/BMHIM.21000057
Bol Med Hosp Infant Mex. 2021;78(6):557-564

www.bmhim.com (http://creativecommons.org/licenses/by-nc-nd/4.0/) 
ambas variables. Con un punto de corte del $30 \%$ de probabilidad de apendicitis perforada se observa una sensibilidad del $77.78 \%$ tanto para RNL como para RPL (razón de verosimilitud +2.37 y +2.14 , respectivamente), y una especificidad del $67.14 \%$ y el $63.57 \%$ para RNL y RPL (razón de verosimilitud -0.33). Conclusiones: Este estudio mostró una asociación significativa de RNL y RPL y la apendicitis aguda perforada. Futuros estudios deberán validar el modelo elaborado y corroborar el desempeño de dichos marcadores.

Palabras clave: Apendicitis. Pediatría. Neutrófilos. Plaquetas sanguíneas. Recuento de linfocitos.

\section{Introduction}

Acute appendicitis $(A A)$ is the most common diagnosis requiring emergency surgery in the pediatric population $^{1}$, with a prevalence of $69 \%$ in this age group ${ }^{2}$, of which $30-75 \%$ of cases progress to perforated appendicitis ${ }^{3}$.

According to some reports, the risk of progression from acute to perforated appendicitis in children is high ${ }^{4}$, with a mortality risk of $\approx 50 \%$. This risk is higher than in the general population ${ }^{5,6}$, mainly due to the difficulty in diagnosing the complication, difficulties in physician-patient communication, and the absence of classic symptoms, resulting in delays in early treatment ${ }^{7,8}$.

The neutrophil-to-lymphocyte ratio (NLR) and platelet-to-lymphocyte ratio (PLR) are emerging as simple, low-cost markers that provide information on the action of two immune and inflammatory pathways ${ }^{9,10}$. These parameters have even been proposed as potential markers for predicting perforated appendicitis ${ }^{11-13}$ because they relate to innate immunity, which has an initial action on the inflammatory process and the longterm response of the immune system. Although studies have been performed in adult and elderly populations, there is uncertainty about using these markers in the pediatric population.

In countries with scarce health resources, such as Peru, these markers could help to identify patients at potential risk of perforated appendicitis in order to prioritize their admission to surgical wards, considering that surgical care times for appendicitis are usually long, which could lead to worse outcomes in this group of patients ${ }^{14,15}$. Therefore, this study aimed to evaluate the potential clinical utility of NLR and PLR as markers for the early diagnosis of acute perforated appendicitis in the pediatric population.

\section{Methods}

\section{Study design}

We conducted an observational, analytical cross-sectional study in which we performed a secondary analysis of a database of pediatric patients attended at the Regional Hospital of Ayacucho.

\section{Study population, sample, and selection criteria}

The study population consisted of all pediatric patients under 16 years of age at the time of diagnosis and who underwent appendectomy for acute appendicitis at the Regional Hospital of Ayacucho between January 2017 and December 2019.

For the present analysis, we obtained a non-random sample, in which we included all patients with an intraoperative diagnosis of acute appendicitis. We excluded those patients $<5$ years of age (due to the essential physiological differences in lymphocyte counts below this age $)^{16}$ who reported having pathologies that altered the NLR and PLR ${ }^{17}$, who had consumed any drug before admission, and who did not have any of the variables of interest reported.

\section{Procedures}

The necessary permissions were requested for access to the patient database and patient medical records. An author verified the data reliability by contrasting the information collected with the clinical history of each patient. Considering previous research, we also included variables that were not initially included but were necessary for the study and added them to the database ${ }^{11,18}$.

\section{Outcome: perforated appendicitis}

The diagnosis of non-perforated appendicitis was defined as congestive or catarrhal, phlegmonous or suppurative, gangrenous or necrotic appendicitis, and without macroscopic perforations or free fluid. In contrast, perforated appendicitis was defined by the presence of macroscopic perforations in the appendix and the presence of free intra-abdominal fluid. This variable was assessed based on the intraoperative report of each patient. 

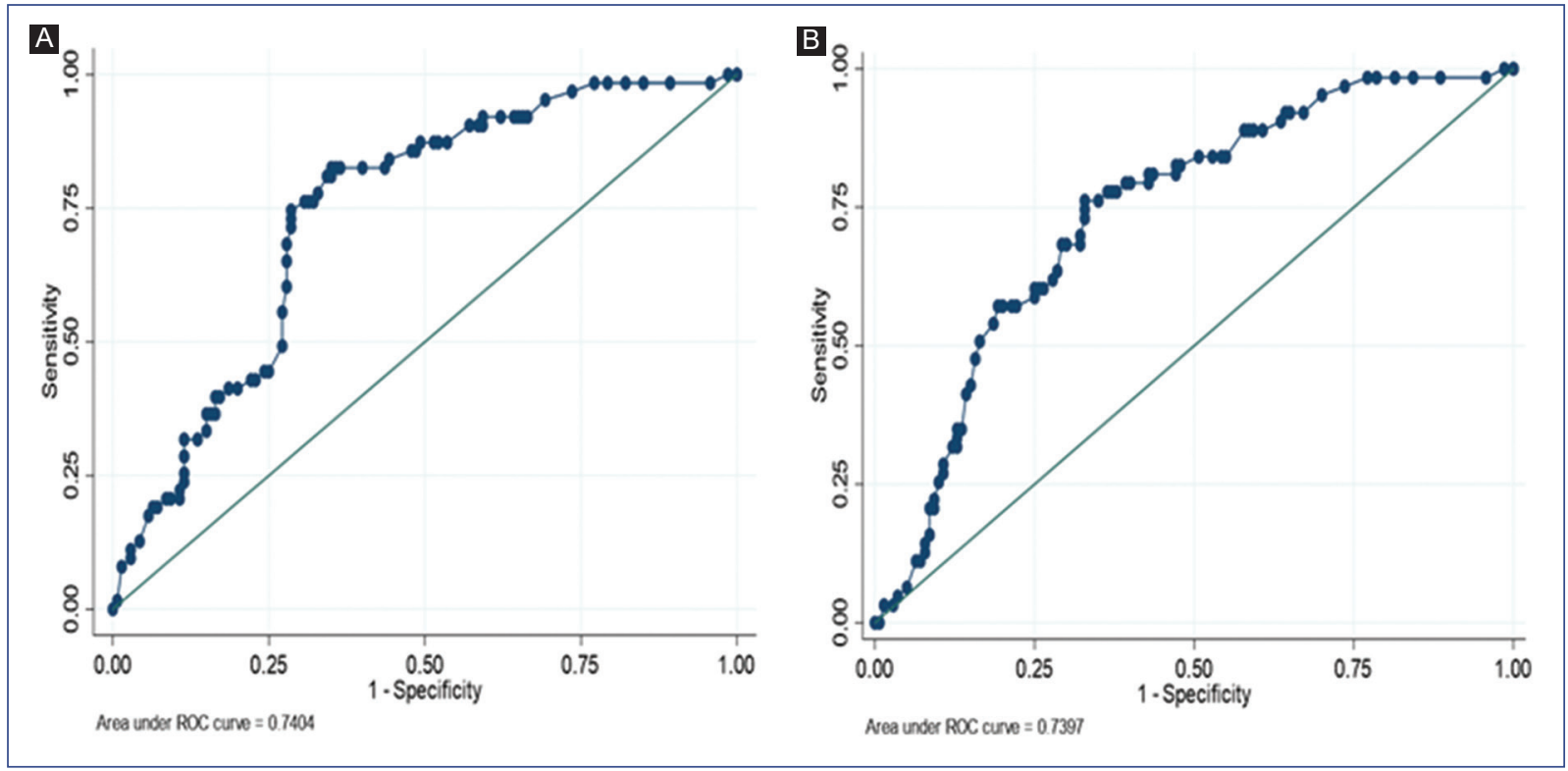

Figure 1. Receiver operating characteristic (ROC) curves of the predictive models. A. Predictive model for acute appendicitis and neutrophil-to-lymphocyte ratio, adjusted for age, sex, and leukocytes. B. Predictive model for acute appendicitis and platelet-to-lymphocyte ratio, adjusted for age, sex, and leukocytes.

\section{Independent variables}

The leading independent variables were the NLR and PLR ratios. To obtain the NLR value, we divided the absolute number of neutrophils by the absolute number of lymphocytes, and for PLR, the absolute number of platelets by the absolute number of lymphocytes, as recommended elsewhere ${ }^{16}$. We decided to categorize the NLR and PLR variables considering the established cut-off points for the pediatric population proposed in published studies $^{18}$. Therefore, categorical variables were obtained for both cases (NLR: $\leq 10.4$ and > 10.4; PLR: $\leq 284$ and >284).

Other variables were also evaluated, such as sex (male and female) and age (years), and clinical characteristics, such as fever, abdominal pain, nausea, vomiting, and diarrhea. Also, laboratory values such as leukocytes ( $\leq 15000$ and $>15000$ cells $\left./ \mathrm{mm}^{3}\right)$, neutrophils, lymphocytes, and their absolute values from the complete blood count were performed when the patient was admitted to the hospital. All the laboratory values were processed at the Regional Hospital of Ayacucho.

\section{Statistical analysis}

We used the Stata v.15 statistical software for data analysis. A descriptive analysis of the study population was performed using absolute and relative frequencies for categorical variables and central tendency and dispersion measures for numerical variables. The distribution of the variables was evaluated using quantiles plots.

The relationship between NLR and PLR and perforated appendicitis was calculated using logistic regression models, in which the odds ratio $(\mathrm{OR})$ and their respective confidence intervals $(95 \% \mathrm{Cl})$ were obtained. To develop multiple models, we considered including known variables that could affect the primary relationship, such as age, sex, leukocytes $>15000$ cells $/ \mathrm{mm}^{3}$, as reported previously, ${ }^{5,19}$. In addition, a sensitivity analysis was performed to compare the model created, including the confounding variables and the NLR/PLR vs. the model without the NLR/PLR variables, to determine the contribution of the primary variables NLR and PLR.

For the selected multiple regression models, receiver operating characteristic (ROC) curves were plotted, and their respective areas under the curve (AUC) were estimated. A cut-off point of 0.29 was chosen as the probability of having the outcome because it reports a better balance between its sensitivity, specificity, positive likelihood ratio (LR+), and negative likelihood ratio (LR-) values (Figure 1).

\section{Ethical aspects}

The present study is based on secondary analysis. No individuals were contacted, so the risks were minimal. Anonymity and confidentiality of the participants' data were maintained by coding each one of the individuals. 
Table 1. Clinical characteristics of the patients with appendicitis $(n=203)$

\begin{tabular}{|c|c|c|c|c|}
\hline \multirow[t]{2}{*}{ Variable } & \multirow[b]{2}{*}{ n (\%) } & \multicolumn{2}{|c|}{ Perforated appendicitis } & \multirow[b]{2}{*}{$p$-values } \\
\hline & & $\begin{array}{c}\text { No } \\
140(68.97)\end{array}$ & $\begin{array}{c}\text { Yes } \\
63(31.03)\end{array}$ & \\
\hline \multicolumn{5}{|c|}{ Sociodemographic characteristics } \\
\hline $\begin{array}{l}\text { Sex } \\
\text { Male } \\
\text { Female }\end{array}$ & $\begin{array}{c}110(54.19) \\
93(45.81)\end{array}$ & $\begin{array}{l}67(60.91) \\
73(78.49)\end{array}$ & $\begin{array}{l}43(39.09) \\
20(21.51)\end{array}$ & 0.007 \\
\hline Age & $10.98 \pm 3.10^{*}$ & $11.39 \pm 3.04^{*}$ & $10.08 \pm 3.07^{*}$ & 0.005 \\
\hline \multicolumn{5}{|c|}{ Clinical features } \\
\hline $\begin{array}{l}\text { Fever } \\
\text { No } \\
\text { Yes }\end{array}$ & $\begin{array}{c}137(67.49) \\
66(32.51)\end{array}$ & $\begin{array}{c}104(75.91) \\
36(54.55)\end{array}$ & $\begin{array}{l}33(24.09) \\
30(45.45)\end{array}$ & 0.002 \\
\hline $\begin{array}{l}\text { Abdominal pain } \\
\text { No } \\
\text { Yes }\end{array}$ & $\begin{array}{c}1(0.49) \\
202(99.51)\end{array}$ & $\begin{array}{c}1(100) \\
139(68.81)\end{array}$ & $\begin{array}{c}0(0) \\
63(31.19)\end{array}$ & 0.501 \\
\hline $\begin{array}{l}\text { Vomiting } \\
\text { No } \\
\text { Yes }\end{array}$ & $\begin{array}{c}4(46.31) \\
109(53.69)\end{array}$ & $\begin{array}{l}70(74.47) \\
70(64.22)\end{array}$ & $\begin{array}{l}24(25.53) \\
39(35.78)\end{array}$ & 0.116 \\
\hline $\begin{array}{l}\text { Nausea } \\
\text { No } \\
\text { Yes }\end{array}$ & $\begin{array}{c}170(83.74) \\
33(16.26)\end{array}$ & $\begin{array}{c}112(65.88) \\
28(84.85)\end{array}$ & $\begin{array}{c}58(34.12) \\
5(15.15)\end{array}$ & 0.031 \\
\hline $\begin{array}{l}\text { Diarrhea } \\
\text { No } \\
\text { Yes }\end{array}$ & $\begin{array}{c}185(91.13) \\
18(8.87)\end{array}$ & $\begin{array}{c}129(69.73) \\
11(61.11)\end{array}$ & $\begin{array}{c}56(30.27) \\
7(38.89)\end{array}$ & 0.451 \\
\hline \multicolumn{5}{|c|}{ Laboratory values } \\
\hline $\begin{array}{l}\text { Leukocytes } \\
\leq 15000 \mathrm{cells} / \mathrm{mm}^{3} \\
>15000 \mathrm{cells} / \mathrm{m}^{3}\end{array}$ & $\begin{array}{c}12.97 \pm 5.28^{*} \\
126(62.07) \\
77(37.93)\end{array}$ & $\begin{array}{c}11.73 \pm 5.05^{*} \\
99(78.57) \\
41(53.25)\end{array}$ & $\begin{array}{c}15.73 \pm 4.73^{*} \\
27(21.43) \\
36(46.75)\end{array}$ & $<0.001$ \\
\hline Neutrophils & $79.20 \pm 13.20^{*}$ & $76.16 \pm 14.12^{*}$ & $85.97 \pm 7.28^{*}$ & $<0.001$ \\
\hline Absolute value of neutrophils & $10.73 \pm 5.28^{*}$ & $9.42 \pm 5.11^{*}$ & $13.64 \pm 4.46^{*}$ & $<0.001$ \\
\hline Lymphocytes & $14.67 \pm 11.80^{*}$ & $17.49 \pm 12.65^{*}$ & $8.40 \pm 6.09^{*}$ & $<0.001$ \\
\hline Absolute value of lymphocytes & $1.49 \pm 0.83^{*}$ & $1.62 \pm 0.85^{*}$ & $1.20 \pm 0.73^{*}$ & 0.001 \\
\hline $\begin{array}{l}\text { Neutrophil-to-lymphocyte ratio } \\
\leq 10.4 \\
>10.4\end{array}$ & $\begin{array}{c}10.81 \pm 10.32^{*} \\
124(61.08) \\
79(38.92)\end{array}$ & $\begin{array}{l}8.40 \pm 7.93^{*} \\
99(79.84) \\
41(51.9)\end{array}$ & $\begin{array}{c}16.16 \pm 12.78^{*} \\
25(20.16) \\
38(48.1)\end{array}$ & $<0.001$ \\
\hline $\begin{array}{l}\text { Platelet-to-lymphocyte ratio } \\
\leq 284 \\
>284\end{array}$ & $\begin{array}{c}269.45 \pm 183.98^{*} \\
134(66.01) \\
69(33.99)\end{array}$ & $\begin{array}{c}233.96 \pm 139.00^{*} \\
103(76.87) \\
37(53.62)\end{array}$ & $\begin{array}{l}348.32 \pm 240.43^{*} \\
31(23.13) \\
32(46.38)\end{array}$ & $<0.001$ \\
\hline
\end{tabular}

\section{Results}

Of the 232 pediatric patients surgically intervened for AA at the Regional Hospital of Ayacucho between 2017 and 2019, we excluded 25 due to the absence of data on the variables under study, and four medical records were reported as missing. The final population study was of 203 patients with AA (mean age $10.9 \pm 3.1$ ), of which $31.0 \%$ presented perforated appendicitis.
Of this population, $32.5 \%, 99.5 \%, 53.7 \%, 16.3 \%$, and $8.9 \%$ presented with fever, abdominal pain, vomiting, nausea, and diarrhea, respectively. Furthermore, within the laboratory values we obtained a mean of $10.7 \pm 5.3$ neutrophils (absolute value) and $1.5 \pm 0.8$ lymphocytes (absolute value) (Table 1). We observed that $37.9 \%$ showed values $>15000$ cells $/ \mathrm{mm}^{3}$ of leukocytes, $38.9 \%$ values $>10.4$ in NLR, and $33.9 \%$ values $>284$ in PLR. 
Table 2. Neutrophil-to-lymphocyte ratio and platelet-to-lymphocyte ratio as predictors of acute perforated appendicitis

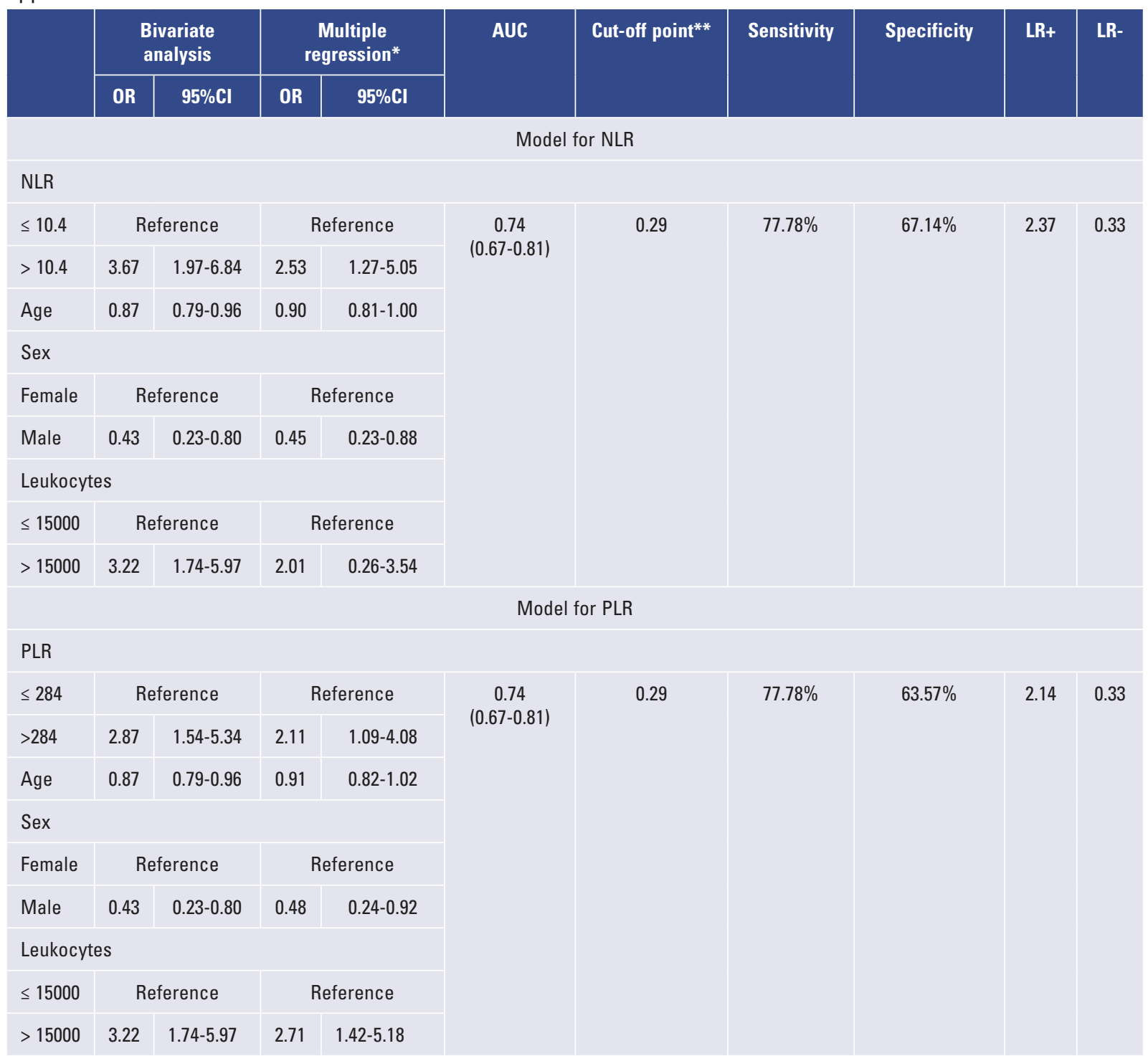

*Adjusted for sex, age, and leukocytes. ${ }^{*}$ Cut-off point for probability.

The estimation of the area under the curve, sensitivity, specificity, and likelihood ratio was performed using the multiple regression model.

AUC, area under the curve; $\mathrm{Cl}$, confidence interval; LR, likelihood ratio; NLR, neutrophil-lymphocyte ratio; PLR, platelet-lymphocyte ratio; $0 R$, odds ratio.

Also, a statistically significant difference was found between the variables sex, age, fever, nausea, leukocytes, neutrophils, lymphocytes, NLR, and PLR, with perforated appendicitis (Table 1).

\section{Predictive model}

In the bivariate analysis, we found a significant association between NLR (> 10.4; OR: $3.67 ; 95 \% \mathrm{Cl}$ 1.97 - 6.84) and PLR values (> 284; OR: $2.87 ; 95 \% \mathrm{Cl}$ 1.54 - 5. 34) with perforated appendicitis, which was maintained when performing the adjusted analysis, where values > 10.4 and > 284 of NLR (OR: 2.53; $95 \% \mathrm{Cl} 1.27-5.05)$ and PLR (OR: $2.11 ; 95 \% \mathrm{Cl}$ 1.09 - 4.08), respectively, were associated with an increased risk of perforated appendicitis (Table 2).

When comparing the multiple regression models with and with no NLR and PLR variables, we observed an improvement in the values of the likelihood ratios and pseudo $\mathrm{R}^{2}$ when adding the NLR (with no variables: log-likelihood $=-113.25$, pseudo $R^{2}=0.099$; with variables: log-likelihood $=-109.76$, pseudo $R^{2}=0.127$ ) and PLR (with no variables: log-likelihood $=-113.25$, pseudo 
$\mathrm{R}^{2}=0.099$; with variables: log-likelihood $=-110.82$, pseudo $R^{2}=0.118$ ). Considering that NLR and PLR variables contributed significantly to the multiple regression models, we decided to select the models that included the main variables.

Both models created for NLR and PLR performed well as markers of perforated appendicitis with an AUC of $0.74(0.67-0.81)$ for both variables.

Finally, for a cut-off point of the probability of having perforated appendicitis of $30 \%$, we observed sensitivity of $77.78 \%$ for both NLR and PLR (likelihood ratio +2.37 and +2.14 , respectively), and a specificity of $67.14 \%$ and $63.57 \%$ for NLR and PLR (likelihood ratio -0.33 ), respectively.

\section{Discussion}

Our study evaluated a population of patients with AA to assess two potential markers for the diagnosis of perforated appendicitis. Besides abdominal pain, we found that vomiting was present in more than half of the children with $\mathrm{AA}$, consistent with a previous study conducted in Turkey, where $100 \%$ and $56 \%$ of the children indicated abdominal pain and presented vomiting, respectively ${ }^{18}$. In contrast, another study in the United States reported absent symptoms in children with pathologically established appendicitis ${ }^{8}$.

While it is true that these symptoms and their severity could be helpful for diagnosis, we must consider that many of the clinical data are referred by the patient, which makes them of little use in young children due to their limited ability to communicate their symptoms ${ }^{20}$. Furthermore, there is no typical pattern in the clinical features of AA in children, so complementary diagnostic tools are required to diagnose appendicitis and detect complications such as perforation ${ }^{8}$.

\section{Perforated appendicitis}

We found perforated appendicitis in more than onethird of the population studied. Similar figures have been reported in Turkey ${ }^{21}$ and the United States ${ }^{7}$, where approximately $30 \%$ and $24 \%$ of children, respectively, presented with perforated appendicitis. The percentage found is higher than other age groups, which may be because the diagnosis of appendicitis in children is generally difficult and may progress to perforated appendicitis $^{6,20,22}$.

Perforated appendicitis occurs more commonly in young children because they are less able to understand or articulate their developing symptomatology compared with adolescents. Therefore, it impacts low diagnostic accuracy in this age group ${ }^{5}$ and is associated with a delay in inpatient surgical treatment, subsequently leading to a potential risk of perforation ${ }^{3}$. Our findings corroborate this fact, as the patients with perforation were young.

A higher frequency of perforation was observed in males $(39.09 \%$ vs. $21.51 \%)$, similar to a study in Germany, in which males presented with perforated appendicitis more frequently $(66 \%)^{23}$. This higher frequency could be mainly due to differences in the immune response and differences in the characteristics of the intestinal connective tissue between males and females ${ }^{24,25}$. In this regard, it has been observed that women have higher levels of immune activation and higher gene expression associated with inflammation in intestinal mucosa samples, which, in theory, could translate into a lower incidence of perforated appendicitis cases.

Consistent with a study in China ${ }^{13}$, we also found that leukocytes (> 15000 cells $/ \mathrm{mm}^{3}$ ), neutrophils, and lymphopenia were significantly higher in those patients with perforated appendicitis. As both leukocytes and neutrophils are part of the acute inflammatory response, their increase would be involved in the appendix inflammation process and, consequently, its perforation ${ }^{9}$. Lymphopenia is a marker of stress ${ }^{26}$ and infectious pathologies $^{27}$, and its reduction is associated with the progression of appendicitis infection, especially after 6 hours ${ }^{28}$.

\section{Markers for perforated appendicitis}

NLR is a commonly available biomarker that conveys information about inflammatory condition ${ }^{10}$ because neutrophils signal and are part of the immune response, which helps the body initiate and maintain a sustained response $^{9}$. Therefore, it would be expected that the higher the NLR value, the more excessive and uncontrolled the immune response will be due to tissue destruction mediated by the inflammatory process, leading to perforation ${ }^{29}$. In this case, predictive models have reported that NLR values $>10.4$ would more precisely indicate the development of perforated appendicitis $^{18}$.

We evaluated the NLR considering a cut-off point of 10.4 and found a statistically significant association between NLR and perforated appendicitis, with a sensitivity of approximately $78 \%$ and a specificity of $67 \%$ for a probability of perforated appendicitis of $29 \%$. 
Although the use of NLR as a diagnostic marker in perforated appendicitis has been previously studied, primarily adult and elderly populations have been included ${ }^{11-13}$. Higher sensitivities were found in a South Korean (78\%), and a Turkish (81\%) study, whereas a lower sensitivity was reported in another study conducted in Turkey (64\%). Additionally, these three studies reported lower specificity $(66 \%, 53 \%$, and $64 \%$, respectively). These results may be because NLR measurement can potentially be impaired in adults and elderly individuals due to increased NLR when one of the following pathologies is present: high blood pressure, diabetes mellitus, metabolic syndrome ${ }^{30}$, left ventricular dysfunction, acute coronary syndrome, valvular heart disease, abnormal thyroid function, renal or hepatic dysfunction, malignancy ${ }^{31,32}$, local or systemic infection, previous history of infection ( $<3$ months), inflammatory disease, any medications related to the inflammatory condition and obesity ${ }^{17,33}$. In contrast, these conditions are not commonly found in pediatric patients. For this case, we found only one study that evaluated the NLR as a predictor of complicated AA in the pediatric population, which reported similar sensitivity $(61 \%)$ and specificity $(73 \%)$ values to those in our population ${ }^{18}$. Therefore, these findings could suggest that the use of this marker would be reproducible in different populations.

We also found a good performance of the final model, including NLR (AUC $=0.74$ ) with relatively higher values than those reported in studies from Turkey ${ }^{12}$ and $\mathrm{Korea}^{11}$, which may be a consequence of the differences in the included population ${ }^{17}$. However, the values were similar to those reported in a pediatric population in Turkey ${ }^{18}$, with an NLR performance of only 0.71 . If adjusted for other known predictors, this value could have been higher or even equal to that observed in our population.

Furthermore, we found a higher probability of perforated appendicitis for PLR values $>284$, with a sensitivity of $77 \%$ and a specificity of $64 \%$ in the final model. These percentages are far from those reported in studies conducted in Turkey, both in adult ${ }^{13}$ and pediatric populations ${ }^{18}$. In general, PLR can be affected by the lymphocyte count, which is influenced by physical and psychological stress, smoking, pregnancy, and others ${ }^{16}$, or even by the platelet count, due to the sampling time, processing, and equipment used for blood anal$y_{s i s^{34}}$. Therefore, the performance of this marker may vary under these circumstances and could present changes in sensitivity and specificity. Regardless, these values demonstrated that PLR could be a good marker for perforated appendicitis.

The hypothesis of the usefulness of this marker originates from the fact that platelets accumulate at sites of vascular injury or inflammation to maintain the leukocytes recruitment necessary for immunopathological responses. Therefore, in the presence of a more significant inflammatory response, platelets increase ${ }^{35}$ and, consequently, the PLR ratio. In this case, we found a good performance of the obtained model, including PLR (AUC = 0.74).

The adequate performance of both NLR and PLR as markers in the development of perforated appendicitis has been demonstrated. However, future studies are required to validate the proposed models, especially in longitudinal designs, for the sole purpose of verifying the performance of these markers.

\section{Strength and limitations}

The present work is one of the few studies exploring markers of appendix perforation in a pediatric population from blood tests, which are commonly used and available in emergency departments. Furthermore, NLR and PLR analysis are affordable and easy to calculate in the clinical setting, making it an effective clinical assessment tool, a valuable complement, and an aid to risk stratification.

As these markers could be used to indicate appendix perforation, which would allow determining antibiotic coverage and timely use of laparoscopic surgery, further research based on these markers should be continued.

However, some limitations should be considered. First, patients $<5$ years of age were not included, so our results cannot be extrapolated to the entire pediatric population. In addition, as this was an analysis of a secondary database, some critical variables could not be included in the final model, such as the time elapsed since symptom onset.

In future research on this topic, we recommend a prospective study with a larger sample, considering some methodological, physiological, and pathological confounding factors, which could make the significance of NLR and PLR analysis in pediatric perforated appendicitis more powerful.

The present study evidenced an adequate performance of NLR and PLR as markers of perforated appendicitis. NLR values $>10.4$ and PLR $>284$ were significantly associated with perforated appendicitis in pediatric patients. Future studies should validate the 
proposed models, including variables not contemplated in this study and longitudinal designs.

\section{Ethical disclosures}

Protection of human and animal subjects. The authors declare that no experiments were performed on humans or animals for this study.

Confidentiality of data. The authors declare that they have followed the protocols of their work center on the publication of patient data.

Right to privacy and informed consent. The authors have obtained the written informed consent of the patients or subjects mentioned in the article. The corresponding author has this document.

\section{Conflicts of interest}

The authors declare no conflict of interest.

\section{Funding}

None.

\section{References}

1. Barrett ML Hines AL, Andrews RM. Trends in rates of perforated appendix, 2001-2010. HCUP Statistical Brief \#159. Rockville: Agency for Healthcare Research and Quality; 2013.

2. Tseng YC, Lee MS, Chang YJ, Wu HP. Acute abdomen in pediatric patients admitted to the pediatric emergency department. Pediatr Neonatol. 2008;49:126-34

3. Papandria D, Goldstein SD, Rhee D, Salazar JH, Arlikar J, Gorgy A et al. Risk of perforation increases with delay in recognition and surgery for acute appendicitis. J Surg Res. 2013;184:723-9.

4. Pham XD, Sullins VF, Kim DY, Range B, Kaji AH, de Virgilio CM, et al. Factors predictive of complicated appendicitis in children. J Surg Res. 2016;206:62-6.

5. Singh M, Kadian YS, Rattan KN, Jangra B. Complicated appendicitis: analysis of risk factors in children. Afr J Paediatr Surg. 2014;11:109-13.

6. Humes DJ, Simpson J. Acute appendicitis. BMJ. 2006;333:530-4.

7. Ebell MH, Shinholser J. What are the most clinically useful cut-offs for the Alvarado and Pediatric Appendicitis Scores? A systematic review. Ann Emerg Med. 2014;64:365-72.e2.

8. Glass CC, Rangel SJ. Overview and diagnosis of acute appendicitis in children. Semin Pediatr Surg. 2016;25:198-203.

9. Nathan C. Neutrophils and immunity: challenges and opportunities. Nat Rev Immunol. 2006;6:173-82.

10. Balta S, Ozturk C, Balta I, Demirkol S, Demir M, Celik T, et al. The neutrophil-lymphocyte ratio and inflammation. Angiology. 2016:67:298-9.

11. Jung SK, Rhee DY, Lee WJ, Woo SH, Seol SH, Kim DH, et al. Neutrophil-to-lymphocyte count ratio is associated with perforated appendicitis in elderly patients of emergency department. Aging Clin Exp Res. 2017;29:529-36.
12. Sevinc MM, Kınacı E, Cakar E, Bayrak S, Özakay A, Aren A et al. Diagnostic value of basic laboratory parameters for simple and perforated acute appendicitis: an analysis of 3392 cases. Ulus Travma Acil Cerrahi Derg. 2016;22:155-62.

13. Pehlivanlı $F$, Aydin O. Role of platelet to lymphocyte ratio as a biomedical marker for the pre-operative diagnosis of acute appendicitis. Surg Infect (Larchmt). 2019;20:631-6.

14. Bessoff KE, Forrester JD. Appendicitis in low-resource settings. Surg Infect (Larchmt). 2020;21:523-32.

15. Kakembo N, Grabski DF, Fitzgerald TN, Muzira A, Cheung M, Kisa P, et al. Burden of surgical infections in a tertiary-care pediatric surgery service in Uganda. Surg Infect (Larchmt). 2020;21:130-5.

16. Shete A, Thakar M, Abraham PR, Paranjape R. A review on peripheral blood CD4+ T lymphocyte counts in healthy adult Indians. Indian J Med Res. 2010;132:667-75

17. Balta S, Demirkol S, Unlu M, Arslan Z, Celik T. Neutrophil to lymphocyte ratio may be predict of mortality in all conditions. $\mathrm{Br} \mathrm{J}$ Cancer. 2013;109:3125-6.

18. Celik B, Nalcacioglu H, Ozcatal M, Altuner Torun Y. Role of neutrophil-to-lymphocyte ratio and platelet-to-lymphocyte ratio in identifying complicated appendicitis in the pediatric emergency department. Ulus Travma Acil Cerrahi Derg. 2019;25:222-8.

19. Poudel R, Bhandari TR. Risk factors for complications in acute appendicitis among paediatric population. JNMA J Nepal Med Assoc. 2017;56:145-8.

20. Song CW, Kang JW, Kim JY. Different clinical features and lower scores in clinical scoring systems for appendicitis in preschool children: comparison with school-age onset. Pediatr Gastroenterol Hepatol Nutr. 2018;21:51-8.

21. Turel O, Mirapoglu SL, Yuksel M, Ceylan A, Gultepe BS. Perforated appendicitis in children: antimicrobial susceptibility and antimicrobial stewardship. J Glob Antimicrob Resist. 2019;16:159-61.

22. Rentea RM, Peter SDS, Snyder CL. Pediatric appendicitis: state of the art review. Pediatr Surg Int. 2017:33:269-83.

23. Boettcher M, Günther $P$, Breil T. The Heidelberg Appendicitis Score predicts perforated appendicitis in children. Clin Pediatr (Phila). 2017;56:1115-9.

24. Salö M, Ohlsson B, Arnbjörnsson E, Stenström P. Appendicitis in children from a gender perspective. Pediatr Surg Int. 2015;31:845-53.

25. Sankaran-Walters S, Macal M, Grishina I, Nagy L, Goulart L, Coolidge K, et al. Sex differences matter in the gut: effect on mucosal immune activation and inflammation. Biol Sex Differ. 2013;4:10.

26. Ramaekers LH, Theunissen PM, Went K. Acute lymphopenia, stress, and plasma cortisol. Arch Dis Child. 1975;50:555-8.

27. Grossbard LJ, Desai MH, Lemeshow S, Teres D. Lymphocytopenia in the surgical intensive care unit patient. Am Surg. 1984;50:209-12.

28. Devuyst $O$, Maldague $P$, Francois $P$, Dekeuleneer R, Michaux JL. Time-course of lymphopenia in gangrenous appendicitis. Lancet. 1991:338:1074.

29. Livingston EH, Woodward WA, Sarosi GA, Haley RW. Disconnect between incidence of non-perforated and perforated appendicitis: implications for pathophysiology and management. Ann Surg. 2007;245:886-92.

30. Balta S, Demirkol S, Celik T, Kucuk U, Unlu M, Arslan Z, et al. Association between coronary artery ectasia and neutrophil-lymphocyte ratio. Angiology. 2013;64:627-32.

31. Stotz M, Gerger A, Eisner F, Szkandera J, Loibner H, Ress AL, et al. Increased neutrophil-lymphocyte ratio is a poor prognostic factor in patients with primary operable and inoperable pancreatic cancer. $\mathrm{Br} J$ Cancer. 2013;109:416-21.

32. Szkandera J, Absenger G, Liegl-Atzwanger B, Pichler M, Stotz M, Samonigg $\mathrm{H}$, et al. Elevated preoperative neutrophil/lymphocyte ratio is associated with poor prognosis in soft-tissue sarcoma patients. $\mathrm{Br} J$ Cancer. 2013:108:1677-83.

33. Furuncuoğlu Y, Tulgar S, Dogan AN, Cakar S, Tulgar YK, Cakiroglu B. How obesity affects the neutrophil/lymphocyte and platelet/lymphocyte ratio, systemic immune-inflammatory index and platelet indices: a retrospective study. Eur Rev Med Pharmacol Sci. 2016;20:1300-6.

34. Isik A, Balcik OS, Akdeniz D, Cipil H, Uysal S, Kosar A. Relationship between some clinical situations, autoantibodies, and pseudothrombocytopenia. Clin Appl Thromb Hemost. 2012;18:645-9.

35. Li Z, Yang F, Dunn S, Gross AK, Smyth SS. Platelets as immune mediators: their role in host defense responses and sepsis. Thromb Res. 2011;127:184-8 